\title{
Lack of Association of Interleukin-6 and Interleukin-8 Gene Polymorphisms in Chinese Patients With Systemic Lupus Erythematosus
}

\author{
Chung-Ming Huang, ${ }^{1,5}$ An-Ping Huo, ${ }^{1}$ Chang-Hai Tsai, ${ }^{2}$ Chi-Lan Chen, ${ }^{3}$ \\ and Fuu-Jen Tsai ${ }^{4,5 *}$ \\ ${ }^{1}$ Division of Immunology and Rheumatology, China Medical University Hospital, Taichung, Taiwan \\ ${ }^{2}$ Taichung Healthcare and Management University, Taiwan \\ ${ }^{3}$ Foo Yin Institute of Technology, Kaohsiung, Taiwan \\ ${ }^{4}$ Department of Medicine Genetics, China Medical University Hospital, Taichung, Taiwan \\ ${ }^{5}$ College of Chinese Medicine, China Medical University, Taichung, Taiwan
}

\begin{abstract}
The purpose of this study was to determine whether interleukin (IL)-6 and IL-8 gene polymorphisms were markers of susceptibility to or severity of systemic lupus erythematosus (SLE) in Chinese patients. The study included 150 Chinese patients with SLE. A total of 130 unrelated healthy individuals living in central Taiwan served as control subjects. Polymorphisms of the IL-6 and IL-8 gene were typed from genomic DNA. The genotypes, allelic frequencies, and carriage rates were compared between SLE patients and control subjects. The relationship between allelic frequencies and clinical manifestations of 135 SLE patients was evaluated. There
\end{abstract}

were no statistically significant differences in IL-6 and IL-8 gene polymorphisms between the SLE and control groups (chisquared test, $P=0.53, \chi^{2}=1.27$ and $P=0.44, \chi^{2}=1.62$, respectively). In addition, there was no significant association between the two groups in allelic frequency of IL-6 and IL-8 $(P=0.89$ and $P=0.26$, respectively). We also did not detect any association between the IL- 6 and IL- 8 genotype and clinical or laboratory profiles in SLE patients. The results suggest that the IL- 6 and IL- 8 gene polymorphisms are not related to SLE. J. Clin. Lab. Anal. 20:255-259, 2006. (c) 2006 Wiley-Liss, Inc.

Key words: IL-6; IL-8; SLE; gene polymorphism

\section{INTRODUCTION}

Systemic lupus erythematosus (SLE) is a prototypic immune complex-mediated disease with a broad spectrum of autoimmune phenomena and clinical symptoms. Many immunologic abnormalities have been found in SLE patients, including impaired $\mathrm{T}$ cell responses and dysregulation of B cell activation, leading to B cell hyperactivity and overproduction of autoantibodies $(1,2)$. Cytokines are also known to be involved in the pathogenesis of SLE. It has been shown that alternation in cytokine production and cytokine networks contribute to tolerance defects, B-cell hyperactivity, and impaired cellular immunity in SLE.

Proinflammatory cytokines such as interleukin-1 (IL-1), IL-6, IL-8, and tumor necrosis factor- $\alpha$ (TNF$\alpha)$ are produced primarily by activated macrophages and monocytes. IL-6, a multifunctional cytokine, plays an important role in the regulation of acute phase response $(3,4)$. Finck et al. (5) found that IL-6 accelerated the disease course of autoimmune NewZealand black/NewZealand white (NZB/NZW) F1 mice. Moreover, two studies demonstrated that serum levels of IL-6 are elevated in patients with SLE $(6,7)$. The human IL-6 gene is located on chromosome 7p21. There are four naturally occurring haplotype polymorphisms in the IL-6 promoter $(-174 \mathrm{G} \rightarrow \mathrm{C},-373 \mathrm{~A}(\mathrm{n}) \mathrm{T}(\mathrm{n}),-572$ $\mathrm{G} \rightarrow \mathrm{C},-597 \mathrm{G} \rightarrow \mathrm{A})(8)$. One study suggested that the $-373 \mathrm{~A}(\mathrm{n}) \mathrm{T}(\mathrm{n})$ polymorphism influences rheumatoid

\footnotetext{
*Correspondence to: Fuu-Jen Tsai, Department of Medical Genetics, China Medical University Hospital, No 2 Yuh Der Road, Taichung, Taiwan. E-mail: d0704@www.cmuh.org.tw

Received 16 March 2006; Accepted 8 August 2006 DOI $10.1002 /$ jcla. 20151

Published online in Wiley InterScience (www.interscience.wiley.com).
} 
arthritis (RA) disease progression (9), while another study found an association between the $-174 \mathrm{G} \rightarrow \mathrm{C}$ polymorphism and juvenile chronic arthritis (10). Furthermore, a study of postmenopausal women found that the $-572 \mathrm{G} \rightarrow \mathrm{C}$ polymorphism influences levels of circulating $\mathrm{C}$-reactive protein and bone resorption markers (11). Therefore, the $-572 \mathrm{G} \rightarrow \mathrm{C}$ IL-6 gene polymorphism may be a potential genetic susceptibility factor that could be further evaluated with regard to the risk of SLE.

IL-8, a member of the CXC chemokine family, is a strong chemoattractant for neutrophils and lymphocytes $(12,13)$. IL-8 is upregulated in IgA nephropathy, lupus nephritis, and antineutrophil cytoplasmic antibody (ANCA)-associated vasculitis (14-16). Furthermore, Rovin et al. (17) found that IL-8 -845 C polymorphism is associated with severe lupus nephritis in African Americans. The human IL-8 gene is located on chromosome $4 \mathrm{q} 12-\mathrm{q} 21$. It contains four exons and three introns $(18,19)$. The $3^{\prime}$-untranslated region (UTR) of the IL-8 gene has been suggested to contribute to its posttranscription. We hypothesized that genetic variation in IL-6 and IL-8 might be associated with the risk of developing SLE. Therefore, we studied the $-572 \mathrm{G} / \mathrm{C}$ polymorphism in the IL-6 gene and the $\mathrm{A} / \mathrm{G}$ polymorphism in the $3^{\prime}$ UTR of the IL- 8 gene by comparing allelic and genotypic frequencies between 150 Chinese patients with SLE and 130 healthy individuals living in Taiwan. In addition, we also studied the association between IL-6 and IL-8 and SLE susceptibility and severity by focusing on single nucleotide polymorphisms (SNPs).

\section{MATERIALS AND METHODS}

\section{Patient Selection}

We enrolled 150 patients (136 women and 14 men) with definite SLE according to the 1982 revised American College of Rheumatology (ACR) criteria (20), and 130 sex-, age-matched healthy individuals (120 women and $10 \mathrm{men}$ ) living in central Taiwan served as the control subjects. The age of the SLE patients was 17-68 (mean $28.5 \pm 2.9$ ) years. The age of the volunteers was 18-71 ( mean 29.3 \pm 3.1 ) years . The duration of disease in SLE patients was 1-15 (mean $4.5 \pm 1.4$ ) years. Informed consent was obtained from each patient and control subject involved.

\section{Polymerase Chain Reaction}

The genomic DNA was prepared from peripheral blood by a Genomic DNA isolation reagent kit (Genomaker, Taiwan). Polymerase chain reaction (PCR) was used to identify the genotypes of the IL-6 gene promoter region and IL-8 gene 3'-UTR polymorphisms. PCR of the polymorphisms was performed in a total volume of $50 \mu \mathrm{L}$, containing genomic DNA (2-6 pmol of each primer), $1 \times$ Taq polymerase buffer $\left(1.5 \mathrm{mM} \mathrm{MgCl}_{2}\right)$, and 0.25 units of AmpliTaq DNA polymerase (Perkin Elmer; Foster City, CA). For the IL-6 gene promoter region, the primers used were upstream 5'-GCAAAGTCCTCACTGGGAGGA-3' and downstream 5'-TCTGACTCCATCGCAGCCC-3'. For the IL-8 gene $3^{\prime}$-UTR, the primers used were upstream 5'-CTTTAGTGTTTTTATGTGCTCTCCA- ${ }^{\prime}$ and downstream $5^{\prime}$-GCAAATATGCTTAGGCTTTAACC-3'. The primers were selected according to the studies of Chung et al. (21), and Amoli et al. (22). PCR amplification was performed in a programmable PCR thermal cycler (GeneAmp PCR System 2400, Perkin Elmer). The PCR cycling conditions for IL-6 promoter $-572 \mathrm{G} / \mathrm{C}$ polymorphism examination were as follows: 35 cycles at $95^{\circ} \mathrm{C}$ for $30 \mathrm{sec}, 60^{\circ} \mathrm{C}$ for $30 \mathrm{sec}$, and $72^{\circ} \mathrm{C}$ for $45 \mathrm{sec}$; they were then left to stand at $72^{\circ} \mathrm{C}$, then held at $4{ }^{\circ} \mathrm{C}$. The PCR cycling conditions for examination of the $-2767 \mathrm{~A} / \mathrm{G}$ polymorphism in the $3^{\prime}-\mathrm{UTR}$ of the IL-8 gene were as follows: 35 cycles at $95^{\circ} \mathrm{C}$ for $30 \mathrm{sec}, 55^{\circ} \mathrm{C}$ for $30 \mathrm{sec}$, and $72^{\circ} \mathrm{C}$ for $45 \mathrm{sec}$; they were then left to stand at $72^{\circ} \mathrm{C}$, then held at $4^{\circ} \mathrm{C}$.

The polymorphisms of the respective genes of interest were discerned by digestion with BsrBI and ApaLI, respectively. The PCR products were mixed separately using the aforementioned enzymes and reaction buffer according to the manufacturer's instructions; both reactions were incubated for $3 \mathrm{hr}$ at $37^{\circ} \mathrm{C}$. After this, $10 \mu \mathrm{L}$ of each product was loaded into a $3 \%$ agarose gel containing ethidium bromide and subjected to electrophoresis. The resultant genotypes were classified into the categories of nonexcisable homozygote allele (CC and GG for IL-6 and IL-8 genes, respectively), excisable homozygote allele (GG and AA for IL-6 and IL-8 genes, respectively), and heterozygote allele (CG and $A G$ for IL-6 and IL-8 genes, respectively).

\section{Statistical Analysis}

The genotype distributions, allelic frequencies, and carriage rates for the IL-6 gene and IL-8 gene polymorphisms for SLE patients and controls were compared using the chi-squared test. Results were considered statistically significant when the probability of findings occurring by chance was less than $5 \%$ $(P<0.05)$. The odds ratios (OR) were calculated from genotypic frequency and allelic frequency with a $95 \%$ confidence interval (CI) for the IL-6 gene and IL-8 gene polymorphisms. 


\section{RESULTS}

The frequencies of the genotypes of IL-6 in the SLE and control groups are shown in Table 1. In the SLE group, 83 patients $(55.3 \%)$ had the CC IL-6 genotype, 61 patients $(40.7 \%)$ had the $\mathrm{C} / \mathrm{G}$ genotype, and six patients $(4.0 \%)$ had the GG genotype. In the control group, 76 people $(58.5 \%)$ had the CC IL-6 genotype, $46(35.4 \%)$ had the C/G IL-6 genotype, and eight (6.1\%) had the GG IL-6 genotype. There were no significant differences in the distribution of the IL- 6 gene $\mathrm{C} / \mathrm{G}$ polymorphism between the SLE and control groups $\left(\chi^{2}=1.27 ; P=0.53\right)$. We also analyzed the relationship between the two groups in allelic frequencies and carriage rate of IL-6 (Table 1). There was no significant association in frequency $(P=0.89)$ and carriage rate $(P=0.82)$ between SLE patients and normal subjects.

Similarly, there was no significant difference in the genotype $(P=0.44)$, allelic frequency $(P=0.26)$ and carriage rate $(P=0.52)$ of IL-8 between SLE patients and normal subjects (Table 2).

TABLE 1. Comparison of IL-6 genotype distributions, allelic frequencies, and carriage rates observed in SLE patients and healthy control subjects*

\begin{tabular}{|c|c|c|c|c|}
\hline IL-6 & $\begin{array}{c}\text { SLE patients } \\
\mathrm{n}=150(\%)\end{array}$ & $\begin{array}{c}\text { Controls } \\
\mathrm{n}=130(\%)\end{array}$ & $P$ & OR $(95 \% \mathrm{CI})$ \\
\hline \multicolumn{5}{|c|}{ Genotype } \\
\hline $\mathrm{CC}$ & $83(55.3)$ & $76(58.5)$ & 0.53 & \\
\hline $\mathrm{C} / \mathrm{G}$ & $61(40.7)$ & $46(35.4)$ & & \\
\hline GG & $6(4.0)$ & $8(6.1)$ & & \\
\hline \multicolumn{5}{|c|}{ Allelic frequencies } \\
\hline $\mathrm{C}$ & $227(75.7)$ & $198(76.2)$ & 0.89 & $0.97(0.67-1.42)$ \\
\hline G & $73(24.3)$ & $62(23.8)$ & & $1.03(0.70-1.49)$ \\
\hline \multicolumn{5}{|c|}{ Carriage rate } \\
\hline $\mathrm{C}$ & $144(96.0)$ & $122(93.8)$ & 0.82 & $0.95(0.63-1.44)$ \\
\hline G & $67(44.7)$ & $54(41.5)$ & & $1.05(0.69-1.59)$ \\
\hline
\end{tabular}

*All $P$-values represent chi-squared test results.
The clinical manifestations and laboratory findings of the SLE patients, given as ACR criteria, are shown in Tables 3 and 4. The association of IL-6 and IL-8 with particular clinical features of SLE was examined in the 135 patients. We did not find any relationship between IL-6 and IL-8 and severity of SLE (i.e., no association with renal or neurologic involvement) in the Chinese patients in this study.

\section{DISCUSSION}

The etiology of SLE is unknown, but both environmental and genetic factors are believed to be involved in the onset of the disease. It has been postulated that genetic polymorphisms affecting cytokine transcription exist in the regulatory regions of proinflammatory cytokine genes, and that such polymorphisms may control the level of inflammation.

Our study was undertaken to identify SNPs in the proinflammatory cytokine IL-6 and IL-8 genes. Very few studies of the relationship between IL-6 and IL-8

TABLE 2. Comparison of IL-8 genotype distributions, allelic frequencies and carriage rates observed in SLE patients and healthy control subjects*

\begin{tabular}{|c|c|c|c|c|}
\hline IL-8 & $\begin{array}{c}\text { SLE patients } \\
\mathrm{n}=150(\%)\end{array}$ & $\begin{array}{c}\text { Controls } \\
\mathrm{n}=130(\%)\end{array}$ & $P$ & OR $(95 \% \mathrm{CI})$ \\
\hline \multicolumn{5}{|c|}{ Genotype } \\
\hline AA & $13(8.7)$ & $17(13.1)$ & 0.44 & \\
\hline $\mathrm{A} / \mathrm{G}$ & $70(46.7)$ & $61(46.9)$ & & \\
\hline GG & $67(44.6)$ & $52(40.0)$ & & \\
\hline \multicolumn{5}{|c|}{ Allelic frequencies } \\
\hline A & $96(32.0)$ & $95(36.5)$ & 0.26 & $0.82(0.58 \sim 1.15)$ \\
\hline G & $204(68.0)$ & $165(63.5)$ & & $1.22(0.87 \sim 1.73)$ \\
\hline \multicolumn{5}{|c|}{ Carriage rate } \\
\hline A & $83(55.3)$ & $78(60.0)$ & 0.52 & $0.88(0.59 \sim 1.29)$ \\
\hline G & $137(91.3)$ & $113(86.9)$ & & $1.14(0.77 \sim 1.68)$ \\
\hline
\end{tabular}

*All $P$-values represent chi-squared test results.

TABLE 3. Relationship between the IL-6 genotype and clinical signs and findings in patients with SLE

\begin{tabular}{|c|c|c|c|c|c|}
\hline & $\mathrm{CC} \mathrm{n}=75(\%)$ & $\mathrm{C} / \mathrm{G} \mathrm{n}=55(\%)$ & GG $n=5(\%)$ & Total $\mathrm{n}=135(\%)$ & $P$ \\
\hline Malar rash & $40(53.3)$ & $30(55.6)$ & $4(80.0)$ & $74(54.8)$ & 0.51 \\
\hline Discoid lupus & $14(18.7)$ & $6(11.1)$ & $1(20.0)$ & $21(15.6)$ & 0.46 \\
\hline Photosensitivity & $38(50.7)$ & $30(55.6)$ & $4(80.0)$ & $72(53.3)$ & 0.43 \\
\hline Mucosal ulcer & $27(36.0)$ & $14(25.9)$ & $2(40.0)$ & $43(31.9)$ & 0.41 \\
\hline Arthritis & $38(50.7)$ & $31(57.4)$ & $4(80.0)$ & $73(54.1)$ & 0.40 \\
\hline Serositis & $17(22.7)$ & $9(16.7)$ & $1(20.0)$ & $27(20.0)$ & 0.67 \\
\hline Glomerulonephritis & $30(40.0)$ & $18(33.3)$ & $2(40.0)$ & $50(37.0)$ & 0.69 \\
\hline Neuropsychiatric & $11(14.7)$ & $4(7.4)$ & $1(20.0)$ & $16(11.9)$ & 0.37 \\
\hline Hematological & $36(48.0)$ & $29(53.7)$ & $1(20.0)$ & $66(48.9)$ & 0.36 \\
\hline Immunology & $61(81.3)$ & $42(77.3)$ & $3(60.0)$ & $106(78.5)$ & 0.47 \\
\hline ANA & $73(97.3)$ & $54(99.9)$ & $5(96.8)$ & $132(97.8)$ & 0.89 \\
\hline
\end{tabular}

ANA, antinuclear antibody. 
TABLE 4. Relationship between the IL-8 genotype and clinical signs and findings in patients with SLE

\begin{tabular}{|c|c|c|c|c|c|}
\hline & AA $n=11(\%)$ & $\mathrm{A} / \mathrm{G} \mathrm{n}=63(\%)$ & GG $n=61(\%)$ & Total $n=135(\%)$ & $P$ \\
\hline Malar rash & $5(45.5)$ & $38(60.3)$ & $31(50.8)$ & $74(54.8)$ & 0.46 \\
\hline Discoid lupus & $1(9.1)$ & $14(22.2)$ & $6(9.8)$ & $21(15.6)$ & 0.14 \\
\hline Photosensitivity & $5(45.5)$ & 37 (58.7) & $30(49.2)$ & $72(53.3)$ & 0.49 \\
\hline Mucosal ulcer & $2(18.2)$ & $21(33.3)$ & $20(32.8)$ & 43 (31.9) & 0.59 \\
\hline Arthritis & $5(45.5)$ & $30(47.6)$ & $38(62.3)$ & $73(54.1)$ & 0.22 \\
\hline Serositis & $4(36.4)$ & $9(14.3)$ & $14(23.0)$ & $27(20.0)$ & 0.18 \\
\hline Glomerulonephritis & $7(63.6)$ & $21(33.3)$ & $22(36.1)$ & $50(37.0)$ & 0.15 \\
\hline Neuropsychiatric & $1(9.1)$ & $9(14.3)$ & $6(9.8)$ & $16(11.9)$ & 0.71 \\
\hline Hematological & $4(36.4)$ & $32(50.8)$ & $30(49.2)$ & $66(48.9)$ & 0.68 \\
\hline Immunology & $10(90.9)$ & $49(77.8)$ & $47(77.0)$ & $106(78.5)$ & 0.58 \\
\hline ANA & $10(90.9)$ & $61(96.8)$ & $61(100)$ & $132(97.8)$ & 0.13 \\
\hline
\end{tabular}

ANA, antinuclear antibody.

gene polymorphisms and SLE have been reported $(17,23,24)$. Fugger et al. (23) demonstrated that there were no significant differences between healthy control groups and three disease groups [RA $(n=24)$, juvenile rheumatoid arthritis (JRA) $(\mathrm{n}=48)$, and $\operatorname{SLE}(\mathrm{n}=30)$ ]. Although the number of SLE patients was rather small in that study, the result was similar to that found in our present study $(\mathrm{n}=150)$. Linker-Israeli et al. (24) showed that the $3^{\prime}$ minisatellite alleles of the IL-6 gene have biologic significance in SLE patients. However, there was no statistical association between SLE patients $(\mathrm{n}=146)$ and the alleles in the $5^{\prime}$ promoter region (at -174 ) of the IL-6 gene. Rovin et al. (17) found that the IL-8 -854 C polymorphism might predispose African Americans with SLE nephritis to more severe renal injury, perhaps by influencing IL-8 expression. In this study, we examined the relationship between the IL-6 promoter $-572 \mathrm{G} / \mathrm{C}$ polymorphism and the $-2767 \mathrm{~A} / \mathrm{G}$ polymorphism in the $3^{\prime}$-UTR of IL-8 gene and Chinese patients with SLE in Taiwan. In our present study, there were no significant differences in the distribution of IL-6 and IL-8 gene polymorphisms between subjects in the healthy control group and patients in the SLE group. There was also no significant association between the two groups in allelic frequency and carriage rate. Similarly, we did not find any relationship between IL-6 and IL-8 and severity of SLE (i.e., no association with renal or neurologic involvement) in Chinese patients.

There are two possible reasons for the lack of association between IL-6 and IL- 8 gene SNP and SLE found in the present study that are worth further discussion. First, the number of patients $(n=150)$ and controls $(n=130)$ in the present study was relatively small, which may have caused a type II error. Therefore, a similar study involving more patients and controls should be conducted. Second, the cooperative influence of genetic polymorphisms on disease development should also be considered. Therefore, investigation of IL-6 and IL-8 gene SNPs alone may have been inadequate to reveal an association. This argument is supported by a previous study that found that the base differences at distinct polymorphic sites influence each other and do not act independently (25). Further studies of the transcriptional control region as a whole in haplotype polymorphisms may give more information on the genetic basis of disease.

\section{REFERENCES}

1. Horwitz DA, Stohl W, Gray JD. T lymphocytes, natural killer cells, cytokines, and immune regulation. In: Wallace DJ, Hahn BH, editors. Dubois' lupus erythematosus. 5th ed. Baltimore: Williams and Wilkins; 1997. p 155-194.

2. Klinman DM, Steinberg AD. Systemic autoimmune disease arises from polyclonal B cell activation. J Exp Med 1987;165:1755-1760.

3. Houssiau FA, Devogelaer JP, Van Damme J, de Deuxchaisnes CN, Van Snick J. Interleukin-6 in synovial fluid and serum of patients with rheumatoid arthritis and other inflammatory arthritides. Arthritis Rheum 1988;31:784-788.

4. Brozik M, Rosztsoczy I, Mersetey K, et al. Interleukin 6 levels in synovial fluids of patients with different arthritides: correlation with local IgM rheumatoid factor and systemic acute phase protein production. J Rheumatol 1992;19:63-68.

5. Finck BK, Chan B, Wofsy D. Interleukin 6 promotes murine lupus in NZB/NZW F1 mice. J Clin Invest 1994;94:585-591.

6. Linker-Israeli M, Deans RJ, Wallace DJ, Prehn J, Ozeri-Chen T, Klinenberg JR. Elevated levels of endogenous IL-6 in systemic lupus erythematosus. A putative role in pathogenesis. J Immunol 1991;147:117-123.

7. Ripley BJ, Goncalves B, Isenberg DA, Latchman DS, Rahman A. Raised levels of interleukin 6 in systemic lupus erythematosus correlate with anaemia. Ann Rheum Dis 2005;64:849-853.

8. Ishihara K, Hirano T. IL-6 in autoimmune disease and chronic inflammatory proliferative disease. Cytokine Growth Factor Rev 2002;13:357-368.

9. Crilly A, Bartlett JM, White A, Stirling D, Capell H, Madhok R. Investigation of novel polymorphisms within the $37^{\prime}$ region of the IL-6 gene in patients with rheumatoid arthritis using GeneScan analysis. Cytokine 2001;13:109-112.

10. Fishman D, Faulds G, Jeffery R, et al. The effect of novel polymorphisms in the interleukin-6(IL-6) gene on IL-6 transcription and plasma IL-6 levels, and an association with systemiconset juvenile chronic arthritis. J Clin Invest 1998;102:1369-1376. 
11. Ferrari SL, Ahn-Luong L, Garnero P, Humphries SE, Greenspan SL. Two promoter polymorphisms regulating interleukin-6 gene expression are associated with circulating levels of C-reactive protein and markers of bone resorption in postmenopausal women. J Clin Endocrinol Metab 2003;88:255-259.

12. Baggiolini M, Dewald B, Moser B. Interleukin- 8 and related chemotactic cytokines $-\mathrm{CXC}$ and $\mathrm{CC}$ chemokines. Adv Immunol 1944;55:97-179.

13. Shute JK, Lindley I, Peichl P, Holgate ST, Church MK, Djukanovic R. Mucosal IgA is an important moderator of eosinophil responses to tissue-derived chemoattractants. Int Arch Allergy Immunol 1995;107:340-341.

14. Sekidawa T, Kasihara N. Expression of interleukin-8 in human glomerulonephritis. Res Commun Mol Pathol Pharmacol 1998; 99:217-224.

15. Yokoyama H, Wada T, Furuichi K, et al. Urinary levels of chemokines (MCAF/MCP-1, IL-8) reflect distinct disease activities and phases of human IgA nephropathy. J Leukoc Biol 1998; 63:493-499.

16. Cockwell P, Brooks CJ, Adu D, Savage CO. Interleukin-8: a pathogenic role in antineutrophil cytoplasmic autoantibodyassociated glomerulonephritis. Kidney Int 1999;55:852-863.

17. Rovin $\mathrm{BH}, \mathrm{Lu} \mathrm{L}$, Zhang X. A novel interleukin-8 polymorphism is associated with severe systemic lupus erythematosus nephritis. Rapid Communication. Kidney Int 2002;62:261-265.
18. Roebuck KA. Regulation of interleukin-8 gene expression. J Interferon Cytokine Res 1999;19:429-438.

19. Mukaida N, Shiroo M, Matsushima K. Genomic structure of the human monocyte-derived neutrophil chemotactic factor IL-8. J Immunol 1989;143:1366-1371.

20. Tan EM, Cohen AS, Fries JF, et al. The 1982 revised criteria for the classification of systemic lupus erythematosus. Arthritis Rheum 1982;25:1271-1277.

21. Chung HW, Seo JS, Hur SE, et al. Association of interleukin-6 promoter variant with bone mineral density in pre-menopausal women. J Hum Genet 2003;48:243-248.

22. Amoli MM, Thomson W, Hajeer AH, et al. Interleukin 8 gene polymorphism is associated with increased risk of nephritis in cutaneous vasculitis. J Rheumatol 2002;29: 2367-2370.

23. Fugger L, Morling N, Bendtzen K, et al. IL-6 gene polymorphism in rheumatoid arthritis, pauciarticular juvenile rheumatoid arthritis, systemic lupus erythematosus, and in healthy Danes. J Immunogenet 1989;16:461-465.

24. Linker-Israeli M, Wallace DJ, Prehn J, et al. Association of IL-6 gene alleles with systemic lupus erythematosus (SLE) and with elevated IL-6 expression. Genes Immun 1999;1:45-52.

25. Terry CF, Loukaci V, Green FR. Cooperative influence of genetic polymorphisms on interleukin 6 transcriptional regulation. J Biol Chem 2000;275:18138-18144. 